\title{
ACARICIDAL ACTIVITIES OF GARLIC OIL (ALLIUM \\ SATIVUM) AND ITS EFFECTS ON PROTEASE AND ACETYLCHOLINESTERASE (AChE) ACTIVITIES IN RED SPIDER (TETRANYCHUS URTICAE)
}

\author{
Ali, N. A. ${ }^{(1)}$; Mahmoud, K. W. ${ }^{(1)}$; Srour, H. A. ${ }^{(1)}$ \\ Nafea, E. A. ${ }^{(2)}$ and Diab, Nashwa, E. M. ${ }^{(2)}$ \\ 1) Faculty of Agriculture, Ain Shams University 2) Plant Protection Research \\ Institute, Agriculture Research Center.
}

\begin{abstract}
Red spider (Tetranychus urtica) is one of many plant species feeding mites, which cause large agricultural losses. Garlic oil was investigated as acaricidal source to evaluate its ability to protect plants from mite injury. The red spiders were spread on green bean seedlings for one week then the plants were sprayed with different concentrations of garlic oil $(50,250,1000,2000,5000 \mathrm{ppm})$. The results showed that garlic oil showed an acaricidal activity against red spider in dose and time dependent manner. Also, high and low concentrations of garlic oil inhibit acetyl cholinesterase (AChE), while protease activity was declined due to treatment with 1000, 2000 and $5000 \mathrm{ppm}$ garlic oil. On the other hand, the concentration of 50 and $250 \mathrm{ppm}$ increase the red spider protease activity. We can conclude that the garlic oil exhibited acaricidal activity against red spider. The observed acaricidal effect of garlic oil is highly correlated with the inhibition of acetyl cholinesterase (AChE) and protease activities.
\end{abstract}

Key words: Red spider (Tetranychus urticae), plant extracts, Garlic, AChE, Proteases. 
J. Environ. Sci.

Institute of Environmental Studies and Research - Ain Shams University

\section{INTRODUCTIOIN}

Red spider (tetranychus urticae) is a harmful pest for crops such as vegetables , fruits and ornamental plants.Red spider mite is tremely polyphagous; it can feed on hundreds of plants, including most vegetables, fruits and ornamentalplants. Chemical acaricides such as organophosphate compounds, synthetic pyrethroids and anitraz are used to control mites. Application of these synthetic acaricides for long time results in resistance to these synthetic pesticides, and pesticide residue in the fruits, Graf et al.,(2004). Herbal acaricides are environmental- friendly safe compounds with a very low environmental and mamalion toxicity. Several essential oils were evaluated for their acaricidal activities. Singh et al., (2014). These essential oils including garlic oil containing many natural compounds which showed acaricidal activity. These natural compounds have several mode of action including, repellent activities, cuticle dystruction, growth inhibition, antifeedant, respiration disturbance and removing of eggs. Saxana (1989) and Attia et al., (2011). In addition to these modes of action, natural plant extracts including vegetable oil have most induce any resistance among arthropod pest populations. (Feng and Isman 1995). Also, these natural compounds have very low toxicity to the human which make them a good alternatives to synthetic pesticides.Boyd and Alverson (2000), reported that A.sativumin aqueous solution showed acaricidal and/or repellant effects against the mites. As a result, many plant compounds, the majority of which are alkaloids and terpenoids, have now been known to affect insects' behavior, growth and development, reproduction, and survival. high rates of mortality have been 
found on the two spotted mites fed on the leaves treated with garlic oil. Garlic oil had acaricidal activity and causing high mortality George et al., (2010). The acaricidal activity of garlic oil could be attributed to its contents of diallyldisulfide, diallyltrisulfide, and methyl allyltrisulfide.The aim of the present investigation is to evaluate the acaricidal activity of garlic oil against red spider mite (Tetranychus urtica). Also, The relationship between garlic oil acaricidal activity and its inhibitory effect on spider protease and acetyl cholinesterase (AChE) activities were highlighted.

\section{MATERIALS AND METHODS}

Extraction of garlic oil: Garlic prepared by extraction by hexane (5000 ppm) from garlic bulbs obtained from local market. Oil samples were stored in a dark bottle. Ho et al., (1996)

Bioassay of acaricidal toxicity of garlic oil :Red spider mite (Tetranychus urtica) obtained from plant protection, Department, Faculty of Agriculture, Ain Shams University and spread on green bean seedlings under greenhouse conditions. Thirty of red spider mite adult were released on a healthy green bean seedlings For laboratory evaluation of garlic oil. Final count of mite population was taken for confirmation on number of mite before treatments. Each five concentrations of garlic oil (50, 250, 1000, 2000, and 50000) were sprayed on both surfaces of leaf using glass atomizer. The number of live red spider mite was counted after 1, 2, and 24 h of treatments. Dittrich (1962).

Determination of enzyme activities: Red spider mite was homogenized at $4^{\circ} \mathrm{C}$ in a $0.066 \mathrm{M}, \mathrm{pH} 7.5$ sodium phosphate buffer with $0.2 \%(\mathrm{v} / \mathrm{v})$ of Triton 
$\mathrm{X}-100$. The mixture was centrifuged at $10,000 \mathrm{~g}$ at $4{ }^{\circ} \mathrm{C}$ for $15 \mathrm{~min}$. Supernatants were used to measure the enzyme activity .Meratan et al., (2008). Assay of protease activity: The activity of proteases was assayed by the method of Ortego et al., (2000 ). A working solution of bovine serum albumin (BSA) was made by diluting the standard BSA solution of $1 \mathrm{mg} / \mathrm{mL}$ to 0.1 $\mathrm{mg} / \mathrm{mL}$. In 5 test tubes $200 \mu \mathrm{L}, 400 \mu \mathrm{L}, 600 \mu \mathrm{L}, 800 \mu \mathrm{L}$ and $1 \mathrm{~mL}$ of the BSA working solution was taken and named $1-5$. The volume was maintained at 1 $\mathrm{mL}$ by adding distilled water. A blank was set with only distilled water. $500 \mu \mathrm{L}$ of the crude extract was taken for Bradford assay and $500 \mu \mathrm{L}$ of sterile distilled water was added to make the final volume of $1 \mathrm{~mL}$. The $5 \mathrm{ml}$ of the Bradford reagent was added and after 5 min.of incubation, the absorbance was measured spectrophotemeterically at $595 \mathrm{~nm} .50 \mathrm{uL}$ of BAS $(1 \mathrm{mg} / \mathrm{mL})$ standard solution and around $20 \mathrm{uL}$ of crude extract was taken to calculate the proteolytic activity of the crude.The BSA and enzyme were mixed and the volume was maintained at $200 \mu \mathrm{L}$ by the addition of phosphate buffer. The mixture was incubated for $30 \mathrm{~min}$ and $2.3 \mathrm{~mL}$ of the Bradford reagent was added. After 5 min,the absorbance was measured with the photometerically at $595 \mathrm{~nm}$ against blank with reference to two controls: enzyme only and BSA only. The activity of protease was calculated with the following equation Bradford (1976). One unit of protease activity is defined as amount of enzyme that produces $1 \mu \mathrm{mol}$ of tyrosine per minute at $\mathrm{pH} 9.0$ and $60^{\circ} \mathrm{C}$.

Assay of Acetyl cholinesterase (AChE) activity: Acetyl cholinesterase was determined according to $\mathrm{Wu}$ and Miyata (2005) with acetyl thiocholine ATCh iodide as a substrate in the presence of 5, 5_-dithiobis (2-nitrobenzoic 
acid)DTNB in a $0.066 \mathrm{M}$ phosphate buffer, $\mathrm{pH} 7.8$, at $25^{\circ} \mathrm{C}$. OD was measured at $412 \mathrm{~nm}$. The reaction mixture $(2.0 \mathrm{ml})$ consisted of $0.6 \mathrm{mM} \mathrm{ATCh}, 0.4 \mathrm{mM}$ DTNB and $0.05 \mathrm{ml}$ aliquot of the enzyme solution.

\section{RESULTS AND DISCUSSION}

1-Effects of garlic oil on red spider mortality: The acaricidal activity of different concentrations of garlic oil have been presented in Table (1).The obtained results indicated that all five concentrations showed a remarkable acaricidal effect after 1, 2, and 24 hours of treatment . Garlic oil treatments lead to a complete mortality of acaricides after $2 \mathrm{~h}$ and 24 hours of treatment with concentrations of 2000 and $5000 \mathrm{ppm}$. Also, the data in the same table clearly indicated that, the acaricidal activity of garlic oil is increased by increasing both of time and concentration after treatment. Similar results was reported by many authors who mention that higher concentrations of plant extracts increased the mortality of adult insects and arthropods, such T. urticae Alves et al.,(2002); Castagnoli et al., (2005); Roobakkumar et al., (2010) and Sivira et al., (2011).

The statistical analysis showed significant differences among all mean values of tested materials on mortality. 
Table (1): The mortality percentage of red spider after treatment by different concentrations of garlic oil.

\begin{tabular}{|c|c|c|c|}
\hline \multirow{2}{*}{$\begin{array}{l}\text { Concentration } \\
\text { (ppm) }\end{array}$} & \multicolumn{3}{|c|}{ Percentage of mortality (\%) } \\
\cline { 2 - 4 } Time & $\mathbf{1 h}$ & $\mathbf{2 h}$ & $\mathbf{2 4 h}$ \\
\hline \hline 50 & $26.9 \pm 2.1^{\mathrm{l}}$ & $27.4 \pm 1.3^{\mathrm{k}}$ & $31.8 \pm 0.9^{\mathrm{j}}$ \\
\hline 250 & $42.1 \pm 4.8^{\mathrm{i}}$ & $42.0 \pm 2.2^{\mathrm{i}}$ & $43.5 \pm 1.3^{\mathrm{h}}$ \\
\hline 1000 & $69.6 \pm 2.8^{\mathrm{g}}$ & $71.5 \pm 1.0^{\mathrm{f}}$ & $87.7 \pm 2.1^{\mathrm{e}}$ \\
\hline 2000 & $89.1 \pm 8.5^{\mathrm{d}}$ & $89.5 \pm 6.6^{\mathrm{d}}$ & $96.4 \pm 0.7^{\mathrm{c}}$ \\
\hline 5000 & $97.3 \pm 4.6^{\mathrm{b}}$ & $100.0 \pm 0.0^{\mathrm{a}}$ & $100.0 \pm 0.0^{\mathrm{a}}$ \\
\hline \multicolumn{3}{|c|}{$\mathrm{LSD}=0.47$} \\
\hline
\end{tabular}

\section{Each volute presents the mean of three replicate \pm SD}

\section{2- Toxicity effect of garlic oil on red spider}

Data in Fig. (1) Shows that the lethal dose of $50 \%\left(\mathrm{LD}_{50}\right)$ decreases with an increase in the exposure time of adults of T. urticae to garlic oil, because a residual effect becomes more effective when treatment is presented, whereas a lower $\mathrm{LC}_{50}$ value indicates a better mortality and generating ability. This is consistent with the results, $\mathrm{LC}_{50}$ to garlic oil at 24 hour $(1236.25 \pm 112.63$ ppm) and, 2 hour (3170.00 $\pm 117.33 \mathrm{ppm})$ while the red spider low sensitive to garlic oil at 1 hour $(3360.83 \pm 194.96 \mathrm{ppm}) 2$ hour, Natural products could provide a sustainable solution to the environmental problems caused by the use of synthetic pesticides. Many researches are trying to identify effective natural products to replace them with synthetic pesticides. Considering the probability of plant secondary metabolites being involved in plant-pest interactions, the strategy of randomly isolating, identifying, and bio assaying these compounds may be an effective method of pesticide discovery. As our knowledge of insects, weeds genetically modified crops, pesticides, and chemistry has advanced, we have gained the ability to create tailor-made compounds in order 66 
to protect our food supply. This study illustrated the possibility of using plant extract in controlling Mincognita instead of using chemical pesticides to decrease the environmental pollutants of organophosphates, carbamates and other group of pesticides where the excessive use of organophosphates in agriculture has originated serious problems to the environment Miresmailli.et al (2006)

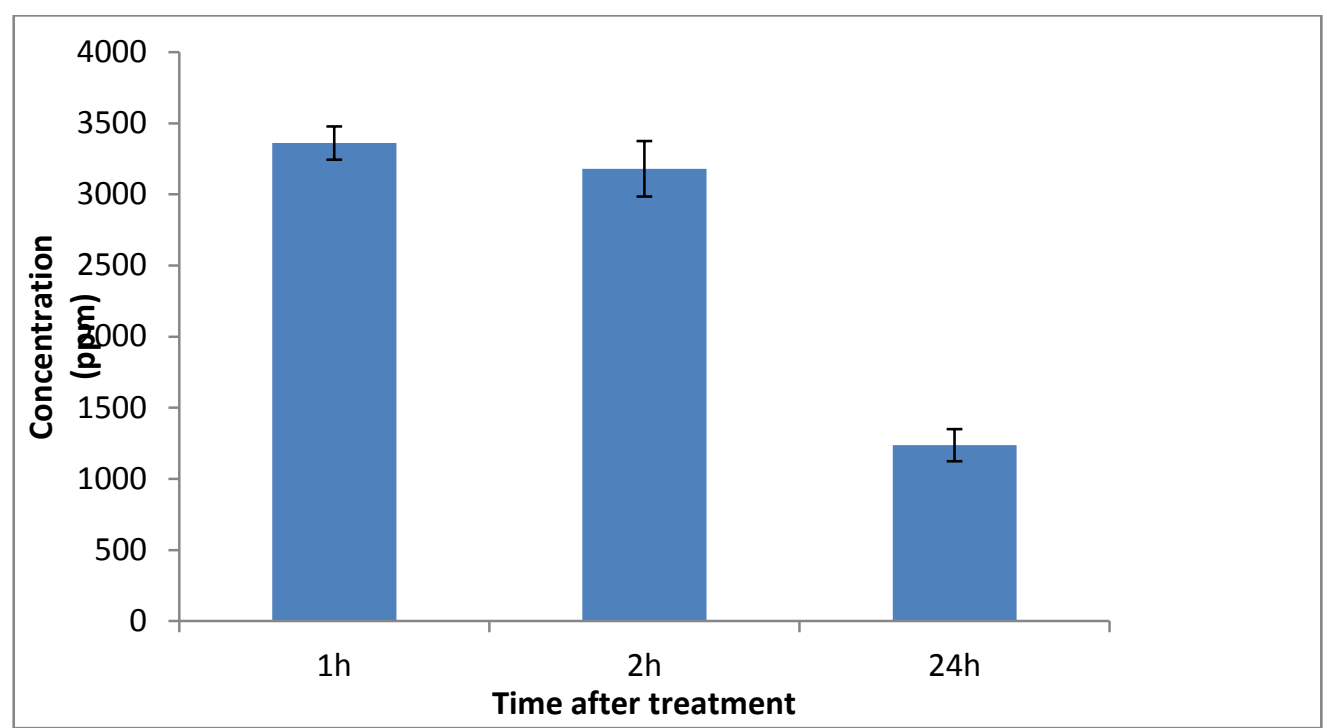

Fig. (1): Effect of garlic oil on red spider toxicity.

Each value presents the mean of three replicate \pm SD

\section{3-Effect of garlic oil on Protease and Acetyl cholinesterase (AChE)} activities in red Spider: Data in Table. (2) Showed that, garlic oil extract caused a significant reduction of protease activity in red spider $(0.75,0.49$, $0.53 \mathrm{mg}$ protein $\mathrm{h}^{-1} \mu \mathrm{g}$ protein ${ }^{-1}$ ), at $1000,2000,5000 \mathrm{ppm}$,comparing with control.Whereas the 50, 250 ppmrecorded a negative effecton red spider protease activity.Garlic oil decreased the activity of acetyl cholinesterase 
(AChE) with all doses, while, protease activity was declined due to treatment with 1000,2000 and 5000 ppm garlic oil. of 50 and 250 ppm increase the red spider protease activity. Also, garlic oil reducedacetyl cholinesterase activity (AChE) at all doses. Christeller (2005) suggested that proteases from a variety of sources (viruses, bacteria, fungi, plants, and insects) have toxicity towards insects.Some of these insecticidal proteases evolved as venom components, herbivore resistance factors, or microbial pathogenicity factors, while other proteases play roles in insect development or digestion, but exert an insecticidal effect when over-expressed from genetically engineered plants or microbial pathogens. Gordon et al.,(2007) reported that the proteases are cysteine proteases, although insect-toxic metalloproteases and serine proteases have also been examined. The sites of protease toxic activity range from the insect midgut to the hemocoel (body cavity) to the cuticle. Amount of Acetyl cholinesterase and resistance to Insecticides-Sensitivity to insecticides is correlated with acetyl cholinesterase content. This mechanism of resistance mediated by over expression has already been described for scavenger or metabolizing proteins. Amplification of esterase genes has been described in mosquitoes Mouchl et al., (1986) and in aphids Field et al., (1988). Over transcription of glutathione transferase gene is also involved in a resistant house fly strain Fournier et al., (1992). Over expression of target proteins has been described for drug resistance Suh et al., (2006) but not yet for insecticide resistance. 
Table (2): Effect of garlic oil on protease and acetyl cholinesterase (AChE) activities in red spider.

\begin{tabular}{|c|c|c|}
\hline $\begin{array}{c}\text { Concentration } \\
(\mathbf{p p m})\end{array}$ & $\begin{array}{c}\text { S. A of Protease activity } \\
\left({\mathrm{mg} \mathrm{protein} \mathrm{h}^{-1} \boldsymbol{\mu g}}^{\left.\text {protein }^{-1}\right)}\right.\end{array}$ & $\begin{array}{c}\text { S. A of (AChE) } \\
\left(\text { nMol.min }{ }^{-1} \mathbf{m g}^{-} \text {protein) }\right.\end{array}$ \\
\hline Control & $1.68 \pm 0.033^{\mathrm{b}}$ & $4.1 \pm 0.07^{\mathrm{a}}$ \\
\hline 50 & $2.26 \pm 0.07^{\mathrm{a}}$ & $3.8 \pm 0.08^{b}$ \\
\hline 250 & $1.73 \pm 0.038^{\mathrm{c}}$ & $3.7 \pm 0.01^{b}$ \\
\hline 1000 & $0.75 \pm 0.007^{\mathrm{d}}$ & $3.2 \pm 0.06^{\mathrm{c}}$ \\
\hline 2000 & $0.49 \pm 0.044^{\mathrm{f}}$ & $2.9 \pm 0.05^{\mathrm{d}}$ \\
\hline 5000 & $0.53 \pm 0.001^{\mathrm{e}}$ & $2.5 \pm 0.02^{\mathrm{f}}$ \\
\hline LSD & 0.0158 & 0.0418 \\
\hline
\end{tabular}

S.A: Specific activity

Each value presents the mean of three replicate \pm SD

Different letters refer to significant differences.

\section{REFRENCES}

Alves, SB, Rossi.,LS, Biaggoni, LR, Tamai, MA, and Pereira (2002): Beauveriabassiana yeast phase on agar medium and its pathogenicity agaiDiatraeasaccharalis (Lepidoptera: Crambidae)and Tetranychusurticae(Acari: Tetranychidae). J. Invertebr. Pathol.81:70-77.

Attia S, Grissa KL, Ghrabi GZ, Lognay G, Mailleux AC and Hance T, (2011): Assessment of the acaricidal activity of several plant extracts on the hytophagousmite Tetranychus urticae (Tetranychidae) in Tunisian citrus or chards Bull RBE/KBVE 147:71 -79.

Boyd, D. W., and D. R. Alverson. (2000): Repellency effectsof garlic extracts on two spotted spider mite, Tetranychus urticae Koch. J. Entomol. Sci. 35: 86-90.

Bradford M.M. (1976): A rapid and sensitive methodfor the quantitation of microgram quantities of proteinutilizing the principle of proteindye binding. Analytical Biochemistry 72: 248 -254. 
Castagnoli M, Liguori M, Simoni S, and DusoC. (2005): Toxicity of some insecticides to Tetranychus urticae, Neoseiulus californicus and Tydeus californicus. Biol..control.50:611-622.

Christeller J.T.(2005): Evolutionary mechanisms acting on proteinease inhibitor variability FEBS Journal 272:5710 - 5722.

Dittrich, V. (1962): A comparative study of toxicological test methods on opulation of the two-spotted spider mite (T.urticae). J. Econ. Entomol. 55 (5): 644- 648.

Feng, R., and M. B. Isman.(1995): Selection for resistance to azadirachtin in the green peach aphid. Myzuspersicae. Experientia 51: 831-833.

Field, L. M., Devonshire, A. L., and Forde, B. G. (1988): Molecular evidence that insecticide resistance in peach-potato aphids (Myzus persicae Sulz.) results from amplification of an esterase gene. Biochem. J. 251, 309- 312.

Fournier, D., Bride, J.M., Poirie, M., Berg\&, J. B., and Plapp, F. W. (1992): Insect glutathione s-transferases biochemical characteristics of the major forms from houseflies susceptible and resistant to insecticides. J. Biol.Chem. 267, 1840-1845.

George DR, Sparagano OAE, Port G, Okello E, Shiel RS and Guy JH, (2010): Toxicity of plant essential oils to different life stages of the poultryred mite Dermayssusgallinae, and non-target invertebrates. Med Vet Entomol 24:9-15.

Gordon, R.; D.; Karbat, I.; Ilan, N.; Cohen, L.; Kahn Gilles, N.; Dong, K.; Stuhmer, W.; Tytgat,J.; Gurevitz, M, (2007): The differential preference of scorpion alpha-toxins for insect or mammalian sodium channels: Implications for improved insect control. Toxicon, 49, 452-472.

Graf E,R , Zhang X, Jin SX, Linh off MW, and Craig A (2004): Neurexins induce differentiation of GABA and glutamate postsynaptic specializations via neuroligins. Cell, 119,1013-26. 
Ho, SH, Koh L, Ma, Y, Huang Y, and Sim KY.(1996): The oil of garlic, Allium sativum L. (Amaryllidaceae), as a potential grain protectant against Triboliumcastaneum (Herbst) andSitophiluszeamaisMotsch. Postharvest Biol.Technol. 9:41-48.

Meratan, A. A.; S.M. Ghaffari and V. Niknam (2008): Effects of salinity on growth, proteins and antioxidant enzymes in three Acanthophyllum species of different ploidy levels. j. sci. 33: 1-8.

Miresmailli S, Bradbury R and Isman MB, (2006): Comparative toxicity of Rosmarinus officinalisL., essential oil and blends of its major constituents against tranychus urticae Koch (Acari: Tetranychidae) on two different host plants. Pest Manag Sci. 62:366-371

Mouchl, C.,Pasteur, N.Berg\&, J. B., Hyrien, O.,Raymond, M.,Robert de S Vincent, B., De Silvestri, M., and Georghiou, G. P.(1986): Amplification of an esterase gene is responsible for insecticide resistance in a California Culex mosquito. Science 233: 778-780.

Ortego, F., Sánchez-Ramos, I., Ruiz, M., and Castañera, P. (2000): Characterization proteases from a stored product mite, Tyrophagusputrescentiae. Arch. Insect Biochem. Physiol. 43: 116124.

Roobakkumar,, A, Subramaniam MSR, Babu, A, and Muraleedharan N (2010): Bioefficacy of certain plant extracts against the red spidermite, Oligonychus

coffeae(Nietner) (Acarina: Tetranychidae)infesting tea in Tamil Nadu, India. Int. J. Acarology 36:255-258.

Saxena, PC, (1989): The role of demographic data in monitoring status of women and recent fertility transition, In Population Planning in India, ed. by Bose A and Desai PB. B.R. Publishing Corporation, Delhi, India, pp. 116-119.

Suh E, Koh S-Y, Lee J-H, Shin K-I, Cho K (2006): Evaluation of resistance pattern to fenpyroximate and pyridaben in Tetranychus urticae collected from greenhouses and apple orchards using lethal concentration-slope relationship. Exp Appl Acarol 38: 151-165 
Singh NK, Jyoti, Vemu B, Nandi A, Singh H, Kumar R, and Dumka VK (2014): Acaricidal activity of Cymbopogon winterianus, Vitex gundo and Withania somnifera against synthetic pyrethroid resistant Rhipicephalus (Boophilus) Parasitol Res. 113: 341-350.

Sivira A, Sanabria ME, Valera N, Vásquez C, (2011): Toxicity of ethanolic extracts from Lippiaoriganoides and Gliricidiasepium to Tetranychuscinn abarinus (Boisduval) (Acari: Tetranychidae).Neotrop. Entomol. 40 (3):375-379.

Wu, G.and Miyata T (2005): Susceptibilities to methamidophos and enzymatic characteristics in 18 species of pest insects and their naturalenemies in crucifer vegetable crops. Pestic BiochemPhysiol 82:79-93

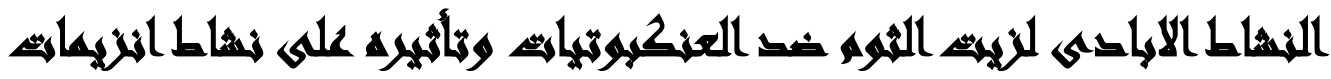

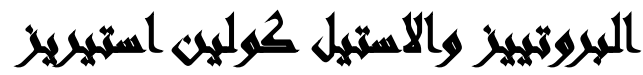

[द]

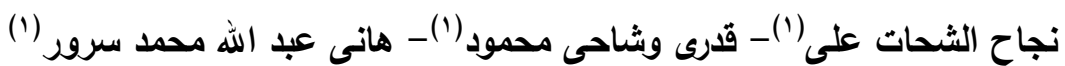

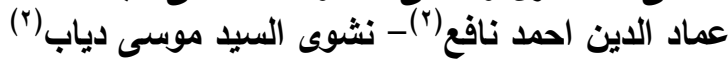

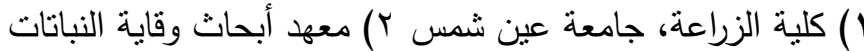

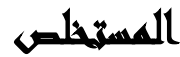

اجريت هذة الدراسة لتقدير النشاط الابادى لمستخلص زيت الثوم (Allium sativum) ضد

العنكبوت الاحمر (Tetranychus urticae) لبحث امكانية استخدام هذا المستخلص كبديل للمبيدات الاكاروسيه لتقليل التلوث البيئى بالمبيدات. لذلك اختبر ناثير هذا المستخلص على نبات الفاصوليا

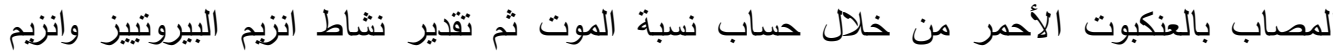

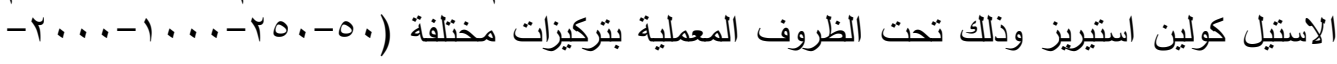

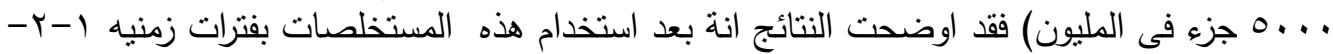

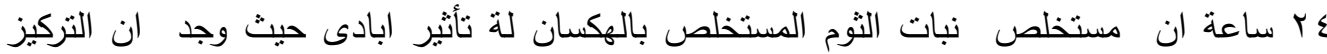

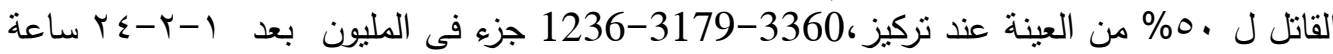

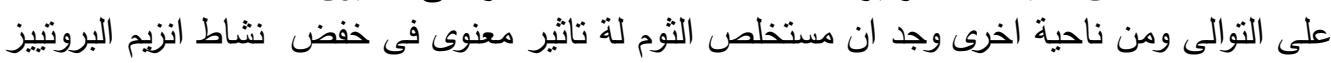

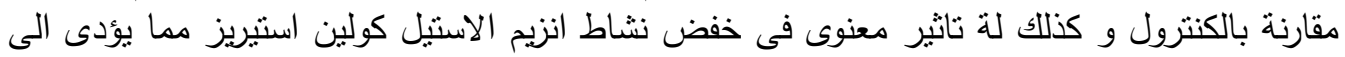


نسبة موت معنوية عالية فى الافة المختبرة لذلك توصى هذة الدراسة بامكانية استخدام مستخلص نبات

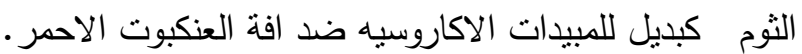

